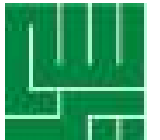

\title{
Hubungan Faktor Lingkungan dan Perilaku Terhadap Kejadian Infeksi Saluran Pernafasan Akut (ISPA) di Desa Talok Kecamatan Kresek
}

\author{
The Correlation Between Environmental Factors and \\ Behavior to the incidence of Acute Respiratory \\ Infections (ARI) in in Talok Village, Kresek District
}

KATA KUNCI KEYWORDS

ABSTRAK
ISPA, Lingkungan ISPA, Perilaku ISPA, Environment, Behaviour
Penyakit Infeksi Saluran Pernafasan Akut (ISPA) masih menjadi salah satu masalah kesehatan masyarakat yang penting untuk diperhatikan, karena merupakan penyakit akut dan bahkan dapat menyebabkan kematian pada balita di berbagai negara berkembang termasuk Indonesia. Salah satu faktor yang mempengaruhi terjadinya ISPA adalah lingkungan dan perilaku masyarakat. Tiga Faktor lingkungan juga dapat disebabkan dari pencemaran udara dalam rumah seperti asap rokok, asap dari dapur karena memasak dengan kayu bakar serta kebiasaan menggunakan obat nyamuk bakar didalam rumah. Beberapa perilaku penduduk yang dapat menimbulkan terjadinya ISPA antara lain meludah sembarangan, membakar sampah, kebiasaan merokok, kebiasaan membuka jendela, dan kebiasaan tidur. Metode penelitian yang digunakan adalah deskriptif analitik dan desain penelitiannya berupa cross-sectional. Data yang diambil merupakan data primer dengan teknik wawancara terpimpin menggunakan kuesioner mengenai faktor lingkungan rumah dan perilaku. Dari 28 responden warga binaan diketahui bahwa terdapat kejadian ISPA pada 23 orang $(82,1 \%)$, terdapat rumah tidak sehat 23 rumah (82,1\%), dan perilaku kurang baik 12 orang $(42,9)$.Dari hasil analisis didapatkan nilai $P=0,007$ terhadap lingkungan, dan $p=0,03$ terhadap perilaku risiko. terdapat hubungan signifikan faktor lingkungan dan perilaku terhadap Kejadian ISPA. 
ABSTRACT Acute Respiratory Infections (ARI) is still one of the important public health issues, because it is an acute disease and can even cause death in infants in various developing countries including Indonesia. One of the factors that influence the occurrence of ARI is the environment and community behavior. Three environmental factors can also be caused from air pollution in the home such as cigarette smoke, smoke from the kitchen because cooking with firewood and the habit of using mosquito coils in the house. Some population behaviors that can cause ARI include careless spitting, burning trash, smoking habits, opening windows, and sleeping habits. The research method used was descriptive analytic and the research design was crosssectional. The data taken is primary data with guided interview techniques using a questionnaire regarding home environment factors and behavior. Of the 28 respondents in the inmates it was found that there was an ARI incidence in 23 people $(82.1 \%)$, there were 23 unhealthy homes $(82.1 \%)$, and 12 unfavorable behavior (42.9). $P=0.007$ for the environment, and $p=0.03$ for risk behavior. There is a significant relationship between environmental and behavioral factors towards ARI events.

\section{PENDAHULUAN}

Konsensus Pertemuan Ahli Infeksi Saluran Pernapasan Akut tahun (2017) menyatakan bahwa penyakit Infeksi Saluran Pernafasan Akut (ISPA) menjadi salah satu masalah kesehatan masyarakat yang penting untuk diperhatikan, karena ISPA merupakan penyakit akut dan bahkan dapat menyebabkan kematian pada balita di berbagai negara berkembang termasuk Indonesia. Infeksi saluran pernafasan atas merupakan penyakit dengan banyak gejala yang bervariasi diawali dengan panas disertai salah satu atau lebih gejala tenggorokan sakit atau nyeri telan, pilek, batuk kering atau berdahak. Tipe virus serta usia, kondisi fisiologis, dan imunologi seseorang juga mempengaruhi gejala-gejala yang muncul. ISPA dapat terjadi tanpa gejala, atau bahkan dapat menyebabkan kematian, namun seringkali penyakit ini muncul sebagai penyakit akut yang dapat sembuh dengan sendirinya.

Dongky dan Kadrianti (2016) menyatakan bahwa di Indonesia kasus ISPA selalu menempati urutan pertama penyebab kematian bayi. Sebanyak $36,4 \%$ kematian bayi pada tahun 2008 $(32,1 \%)$ pada tahun 2009 (18,2\%) pada tahun 2010 dan 38,8\% pada tahun 2011 disebabkan karena ISPA. Selain itu, ISPA sering berada pada daftar sepuluh penyakit terbanyak penderitanya di rumah sakit. Survei mortalitas yang dilakukan Subdit ISPA tahun 2010 menempatkan ISPA sebagai penyebab terbesar kematian bayi di Indonesia dengan persentase $22,30 \%$ dari seluruh kematian balita.

Correspondence:
Dhina Lorenza, Student of Medical Faculty,
Universitas YARSI, Jakarta


Dongky dan Kadrianti (2016) melakukan penelitian di Kelurahan Takatidung Kecamatan Polewal dengan hasil menunjukkan bahwa ada hubungan antara kepadatan hunian yang tidak memenuhi syarat dengan kejadian ISPA pada balita dengan nilai $\mathrm{p}=0,0001(\mathrm{p}<0,05)$. Basuki dan Febriani (2017) menyatakan bahwa ada 3 (tiga) faktor risiko terjadinya ISPA secara umum yaitu faktor lingkungan, factor individu anak, serta faktor perilaku. Faktor lingkungan meliputi pencemaran udara dalam rumah, kondisi fisik rumah, dan kepadatan hunian rumah. Faktor lingkungan yang dimaksud adalah perilaku merokok. Perilaku merokok anggota keluarga akan berdampak kepada anggota keluarga lain khususnya balita, dimana balita menyerap nikotin dua kali lebih banyak dibandingkan orang dewasa. Darmawan (2016) balita juga memiliki sistem kekebalan tubuh yang masih rentan terhadap berbagai penyakit. Menurut Sofia (2017) faktor individu anak meliputi umur anak, berat badan lahir, status gizi, vitamin A, dan status imunisasi. Sedangkan faktor perilaku berhubungan dengan pencegahan dan penanggulangan penyakit ISPA pada bayi dan balita dalam hal ini adalah praktek penanganan ISPA di keluarga baik yang dilakukan oleh ibu ataupun anggota keluarga lainnya. Tiga Faktor lingkungan juga dapat disebabkan dari pencemaran udara dalam rumah seperti asap rokok, asap dari dapur karena memasak dengan kayu bakar serta kebiasaan menggunakan obat nyamuk bakar didalam rumah.

Perilaku hidup bersih dan sehat penduduk merupakan salah satu upaya mencegah terjadinya ISPA dengan memperhatikan rumah dan lingkungannya yang sehat. Beberapa perilaku penduduk yang dapat menimbulkan terjadinya ISPA antara lain meludah sembarangan, membakar sampah, kebiasaan merokok, kebiasaan membuka jendela, dan kebiasaan tidur (Hardati, 2014). Penelitian yang dilakukan sejak tahun 2008 ISPA merupakan penyebab utama kematian pada anak yaitu sebanyak 36,4\% (2008), $32,1 \%$ (2009), 18,2\% (2010), dan 38,8\% (2011), untuk mencegah dan menurunkan tingkat kejadian ISPA pada anak dibutuhkan pengetahuan pada keluarga tentang pentingnya faktor lingkungan, faktor individu, dan faktor perilaku. Dengan demikian tujuan penelitian ini adalah mengetahui hubungan faktor lingkungan dan perilaku dengan kejadian ISPA di desa Talok.

\section{METODE}

Jenis penelitian yang digunakan adalah deskriptif analitik dan desain penelitiannya berupa cross-sectional. Populasi dalam penelitian adalah seluruh keluarga binaan di desa Talok. Pengambilan sampel pada penelitian ini perwakilan dari masing-masing keluarga binaan menggunakan teknik purposive sampling dengan jumlah responden sebanyak 28 orang. Lokasi penelitian dilakukan di Desa Talok RT 01/ RW 01, Kecamatan Kresek, Kabupaten Tangerang, Provisi Banten pada tanggal 2-12 juli 2019 dengan teknik wawancara terpimpin menggunakan kuesioner mengenai faktor lingkungan rumah dan perilaku. Variabel lingkungan di katagorikan rumah sehat dan rumah tidak sehat. Katagori rumah sehat yaitu di nilai dari skor kondisi rumah, sarana sanitasi, dan perilaku penghuni. Variabel perilaku risiko ispa di katagorikan perilaku baik dan perilaku 
kurang baik. Katagori perilaku baik di nilai dari skor menggunakan kayu bakar, kebiasaan membakar sampah, merokok dalam rumah, menggunakan anti nyamuk bakar. Variabel ISPA dikatagorikan dengan ada tidaknya kejadian ISPA dalam 3 bulan terakhir. Data yang diambil merupakan data primer, dengan analisis yang digunakan merupakan bivariat dengan bantuan SPSS versi 23.

\section{HASIL}

Hasil analisis ini disajikan dalam bentuk tabel yang didapat dari data karakteristik responden yang terdiri dari 28 responden di Desa Talok.

Tabel 1. Karakteristik Responden

\begin{tabular}{lcc}
\hline \multicolumn{1}{c}{ Karakteristik } & $\mathbf{N}$ & $\mathbf{\%}$ \\
\hline Pendidikan & & \\
a. Tidak Sekolah & 4 & 14,3 \\
b. Tamat SD/Sederajat & 14 & 50,0 \\
c. Tidak Tamat SMP/Sederajat & 2 & 7,1 \\
d. Tamat SMP/Sederajat & 8 & 28,6 \\
Pekerjaan & & \\
a. IRT & 17 & 60,7 \\
b. Petani & 6 & 21,4 \\
c. Serabutan & 2 & 7,1 \\
d. Tidak Bekerja & 3 & 10,7 \\
Pendapatan & & \\
a. <Rp.1.000.000 & 21 & 75,0 \\
b. Rp.1.000.000-Rp.3.000.000 & 6 & 21,4 \\
c. >Rp.3.000.000 & 1 & 3,6 \\
\hline
\end{tabular}

Berdasarkan tabel diatas di dapatkan sampel pada penelitian ini, Pendidikan tamat SD memiliki presentase terbesar, yaitu sebanyak 14 responden $(50 \%)$, dengan pekerjaan terbanyak adalah IRT, yaitu sebanyak 17 responded (60,7\%). Hampir seluruh responden mimiliki penghasilan dibawah Rp.1.000.000, yaitu 21 responden $(75 \%)$.

Tabel 2. Gambaran Riwayat ISPA

\begin{tabular}{lcc}
\hline \multicolumn{1}{c}{ Riwayat ISPA } & $\mathbf{N}$ & $\mathbf{\%}$ \\
\hline ISPA (-) & 5 & 17,9 \\
ISPA (+) & 23 & 82,1 \\
\hline
\end{tabular}

Berdasarkan table 2, responden dan atau keluarga nya pernah terserang ISPA dalam waktu 3 bulan terakhir yaitu sebanyak 23 orang responden $(82,1 \%)$.

Tabel 3. Gambaran Faktor Lingkungan Rumah

\begin{tabular}{lcc}
\hline Lingkungan Rumah & $\mathbf{N}$ & $\mathbf{0}$ \\
\hline Rumah Sehat & 5 & 17,9 \\
Rumah Tidak sehat & 23 & 82,1 \\
Total & 28 & 100.0 \\
\hline
\end{tabular}

Tabel diatas menunjukan bahwa angka responden yang tinggal di rumah yang termasuk kategori rumah tidak sehat sebanyak 23 responden $(82,1 \%)$. 
Tabel 4. Gambaran Faktor Perilaku Risiko ISPA

\begin{tabular}{lcc}
\hline Perilaku Keluarga & $\mathbf{N}$ & $\mathbf{\%}$ \\
\hline Baik & 16 & 57,1 \\
Kurang baik & 12 & 42,9 \\
\hline
\end{tabular}

Tabel disamping menunjukkan bahwa mayoritas perilaku keluarga responden saat menderita ISPA termasuk kategori baik yaitu sejumlah 16 orang $(57,1 \%)$.

Tabel 5. Hubungan Faktor Lingkungan Dengan Kejadian ISPA

\begin{tabular}{lcccc}
\hline \multirow{2}{*}{ Lingkungan Rumah } & \multicolumn{4}{c}{ Kategori ISPA } \\
\cline { 2 - 5 } & ISPA (-) & ISPA (+) & Total & $\boldsymbol{P}$ \\
\hline Rumah Sehat & $3(60 \%)$ & $2(40 \%)$ & $5(100 \%)$ & \multirow{2}{*}{$\begin{array}{l}\text { P }=0,0007 \\
\text { Rumah Tidak Sehat }\end{array}$} \\
\hline
\end{tabular}

Tabel diatas menunjukan hasil analisis bivariat dengan menggunakan chisquare test diperoleh nilai $p$ sebesar $0.007(p<0.05)$, menggambarkan bahwa faktor lingkungan memiliki hubungan yang bermakna dengan kejadian ISPA.

Tabel 6. Hubungan Perilaku Risiko ISPA Dengan Kejadian ISPA

\begin{tabular}{lcccc}
\hline \multirow{2}{*}{ Perilaku Keluarga } & \multicolumn{4}{c}{ Kategori ISPA } \\
\cline { 2 - 5 } & ISPA (-) & ISPA (+) & Total & $\boldsymbol{P}$ \\
\hline Baik & $5(100 \%)$ & $0(0 \%)$ & $5(100 \%)$ & $P=0,03$ \\
Kurang Baik & $11(47,8 \%)$ & $12(52,2 \%)$ & $23(100 \%)$ & \\
\hline
\end{tabular}

Tabel diatas menunjukan hasil analisis bivariat dengan menggunakan chisquare test diperoleh nilai $\mathrm{p}$ sebesar 0.03 ( $\mathrm{p}<0.05)$, menggambarkan bahwa Perilaku Keluarga memiliki hubungan yang bermakna dengan kejadian ISPA.

\section{PEMBAHASAN}

Penelitian yang dilakukan Wahyuningsih (2017) menyatakan dari tahun ke tahun, prevalensi ISPA di Indonesia tetap tinggi, yaitu sekitar $21,6 \%$ di daerah perkotaan. Hasil Survei Kesehatan Rumah Tangga (SKRT) menunjukkan jumlah balita penderita pneumonia menurun dari 804.937 pada tahun 1999 menjadi 479.283 pada tahun 2000. Namun dari tahun 2000 hingga 2003 jumlah balita penderita ISPA cenderung menetap di angka yang sama meski pemerintah telah mencanangkan program pemberantasan ISPA. World Health Organization (2012) menyatakan secara global, tingkat kematian balita mengalami penurunan sebesar $41 \%$, dari tingkat estimasi 87 kematian per 1000 kelahiran hidup pada tahun 1990 menjadi 51 kematian per 1000 kelahiran hidup pada tahun 2011. Profil Data kesehatan Kresek (2018) menyatakan bahwa ISPA berada pada posisi teratas dari 10 besar penyakit di BLUD Puskesmas Kresek yaitu 9.208, diikuti Hipertensi Essensial sebanyak 3.221, Fharingitis 2.626, DM 1.729, dan Myalgia 1.588, sedangkan yang ke 10 (sepuluh) atau yang terendah yaitu Penyakit Diare sebanyak 794 penderita.

Hasil penelitian yang peneliti lakukan di Desa Talok menunjukan bahwa analisis bivariat pada tabel 5 didapatkan terdapat faktor lingkungan (rumah sehat dan tidak sehat) memiliki 
hubungan yang bermakna dengan kejadian ISPA $(\mathrm{p}=0.007)$,hal ini sejalan dengan penelitian yang dilakukan oleh Taksande dan Yoele (2016) ditemukan bahwa kondisi lingkungan yang tidak tepat, seperti ventilasi yang tidak memadai, bahan bakar untuk memasak yang menyebabkan polusi dalam rumah merupakan faktor resiko signifikan untuk terjadinya ISPA. Penggunaan bahan bakar biomassa (kayu, kotoran hewan), batu bara, minyak tanah dan lainnya, merupakan penyebab yang paling berpengaruh terhadap polusi udara dalam ruangan. Penelitian ini juga sejalan dengan penelitian Dongky dan Kadrianti (2016) yang melakukan penelitian di Kelurahan Takatidung Kecamatan Polewal dengan hasil menunjukkan bahwa ada hubungan antara kepadatan hunian yang tidak memenuhi syarat dengan kejadian ISPA pada balita dengan nilai $p=0,0001$ $(p<0,05)$. Penelitian Ahmad (2018) didapatkan hasil yang sama terhadap pengaruh lingkungan dan angka terjadinya ISPA. Ibu rumah tangga yang tinggal dirumah yang tidak memenuhi standart memiliki resiko 6,6 kali lebih tinggi menderita ISPA dibandingkan yang tinggal di rumah yang memenuhi standart bangunan seperti contohnya bangunan dapur yang tidak menyatu dengan ruangan yang lain, memiliki nilai $(p=1,00)$. Kebiasaan keluarga yang merokok juga memiliki pengaruh dengan $(p=0,14)$ dibandingkan dengan keluarga yang tidak memiliki kebiasaan merokok.

Hasil penelitian pada tabel 6 menyatakan bahwa terdapat hubungan antara perilaku dengan kejadian ISPA di Desa Talok dengan $p=0.03$. Penelitian sesuai dengan penelitian Astuti (2017), perilaku keluarga yang tidak baik dengan balita terkena ISPA sebesar
$76,7 \% \mathrm{P}$ value chisquare sebesar 0,0001 menunjukan arti bahwa perilaku keluarga berhubungan dengan kejadian ISPA. dapat diketahui hasil analisis dengan uji ChiSquare diperoleh nilai signifikan 0,007 yang lebih kecil dari $0,05 \quad(p<0,05) \quad$ sehingga dapat disimpulkan bahwa terdapat hubungan perilaku kesehatan dan kebersihan lingkungan terhadap kejadian ISPA pada balita di Wilayah Kerja Puskesmas Bambanglipuro Bantul Yogyakarta dengan korelasi sedang $(0,40-0,599)$ dan korelasinya positif, arah korelasinya positif artinya semakin buruk perilaku kesehatan dan kebersihan lingkungan bapak/ibu balita maka semakin banyak kejadian ISPA (Pratiwi, 2018). Tingginya prevalensi kejadian ISPA pada anak dinawah usia 5 tahun disebabkan oleh perilaku kurangnya kesadaran akan kebersihan tangan dan tindakan kebersihan lainnya yang meningkatkan risiko terkena pathogen melalui kontak fisik. Anak-anak dapat menularkan virus penyebab ISPA dalam jangka waktu yang lebih lama dibandingkan dengan orang dewasa, sehingga hal ini menyebabkan peningkatan paparan pathogen ke anakanak lainnya lebih tinggi (Solomon et al, 2018).

\section{SIMPULAN DAN SARAN}

\section{Simpulan}

Berdasarkan hasil penelitian diperoleh kesimpulan bahwa faktor lingkungan memiliki hubungan dengan kejadian ISPA dan perilaku tidak memiliki hubungan dengan kejadian ISPA. Banyak faktor lain yang tidak masuk ke dalam analisa seperti usia, pengetahuan, tingkat pendidikan, tingkat penghasilan, dan jenis pekerjaan yang mempengaruhi kejadian ISPA. 


\section{Saran}

Saran dari penulis adalah memasukan faktor-faktor tersebut dalam analisa dan memilih populasi yang lebih besar dalam penilaian hubungan faktor lingkungan dan perilaku dengan kejadian ISPA. Banyak faktor lain yang tidak masuk ke dalam analisa seperti usia, pengetahuan, tingkat pendidikan, tingkat penghasilan, dan jenis pekerjaan yang mempengaruhi kejadian ISPA. Saran dari penulis adalah memasukan faktorfaktor tersebut dalam analisa dan memilih populasi yang lebih besar dalam penilaian hubungan faktor lingkungan dan perilaku dengan kejadian ISPA

\section{Ucapan Terima Kasih}

Terimakasih kepada drg. Trully selaku kepala Puskesmas Kresek, Tangerang, Banten dan Keluarga binaan Desa Talok, Kecamatan Kresek, Kabupaten Tangerang,

\section{KEPUSTAKAAN}

Ahmad $\mathrm{H}$ et al., 2018. The Determinant Factors of Acute Respiratory Infections (ARI) among Housewives in Allakuang Village, South Sulawesi, Indonesia. The 2nd International Meeting of Public Health 2016. p: 503-504

Astuti C 2017. Hubungan Perilaku Keluarga dengan Kejadian ISPA pada Balita

Di Desa Cijati Kecamatan Cimanggu Kabupaten Cilacap. Jawa Barat: http://repository.ump.ac.id/ diakses pada 15 Juli 2019.

Basuki PP, Febriani H 2017. Hubungan Antara Kriteria Perokok dengan Kejadian Infeksi Saluran Pernapasan Akut (ISPA) pada Balita di Wilayah Kerja Kecamatan Prambanan Yogyakarta. 679-687.

Darmawan M, Kumala D, Arsesiana A 2016. Hubungan Tingkat Pengetahuan dan
Sikap Ibu dalam Pemberian ASI Eksklusif dengan Kejadian ISPA pada Bayi Usia 1-12. Dinamika Kesehatan, 7(2):98-109.

Dongky P, Kadrianti 2016. Faktor Risiko Lingkungan Fisik Rumah Dengan Kejadian Ispa Balita Di Kelurahan Takatidung Polewali Mandar. 5(4):325326.

Fibrila F 2015. Hubungan Usia Anak, Jenis Kelamin Dan Berat Badan Lahir Anak Dengan Kejadian Ispa Jurnal Kesehatan Metro Sai Wawai. Jurnal Volume VIII No.2 Edisi Des 2015, ISSN: 19779-469X. Tanjungkarang: Program Studi Kebidanan Metro Politeknik Kesehatan Tajungkarang. diakses https://media.neliti.com/ tanggal 15 Juli 2019.

Hardati, Tri A, Tedi Candra Lesmasna, Susilo Samsul Bahri 2014. Surveilans Epidemiologi Faktor Risiko ISPA pada Balita di Wilayah Kerja Puskesmas Sedayu II Bantul Yogyakarta, Yogyakarta: STIKES Wira Husada Jurnal Kesehatan Masyarakat. 7(1):161166.

IDAI 2015. Memperingati Hari Pneumonia Dunia.

http://www.idai.or.id/artikel/seputa r-kesehatan-anak/memperingati hari pneumonia dunia. Diakses tanggal 25 Juni 2019.

Konsensus 2017. Pertemuan Ahli Infeksi Saluran Pernafasan Atas. https://issuu.com/dhentyf.sa hara/docs/buku_saku_fix. Diakses tanggal 25 Juni 2019.

Pratiwi 2018. Hubungan Perilaku Kesehatan Dan Kebersihan Lingkungan Dengan Kejadian Ispa Pada Balita Di Wilayah Kerja Puskesmas Bambanglipuro Bantul Yogyakarta. p: 3-4.

Sofia 2017. Faktor Risiko Lingkungan Dengan Kejadian Ispa Pada Balita Di Wilayah Kerja Puskesmas Ingin Jaya Kabupaten Aceh Besar. 2(1):43-44.

Ramadhaniyanti GN 2015. Faktor- Faktor Risiko Lingkungan Rumah Dan Perilaku Yang Berhubungan Dengan Kejadian Infeksi Saluran Pernafasan 
ALVIN ARIANO, AYU RETNO BASHIRAH, DHINA LORENZA, MUTHIAH NABILLAH, SANTI NOOR APRILIANA, KHOLIS ERNAWATI

Akut (Ispa) Pada Balita Di Kelurahan Kuningan Kecamatan Semarang Utara. Jurnal Kesehatan Masyarakat. 3(1): 515518.

Wahyuningsih S 2017. Infeksi Saluran Pernafasan Akut (ISPA) pada Balita di Wilayah Pesisir Desa Kore Kecamatan
Sanggar Kabupaten Bima. Higine Jurnal Kesehatan Masyarakat. 3(2): 9899

Wantania JM, Naning R, Wahani A 2012. Infeksi respiratori akut, dalam: Buku ajar respirologi anak IDAI. Jakarta: EGC. P: 268-76. 